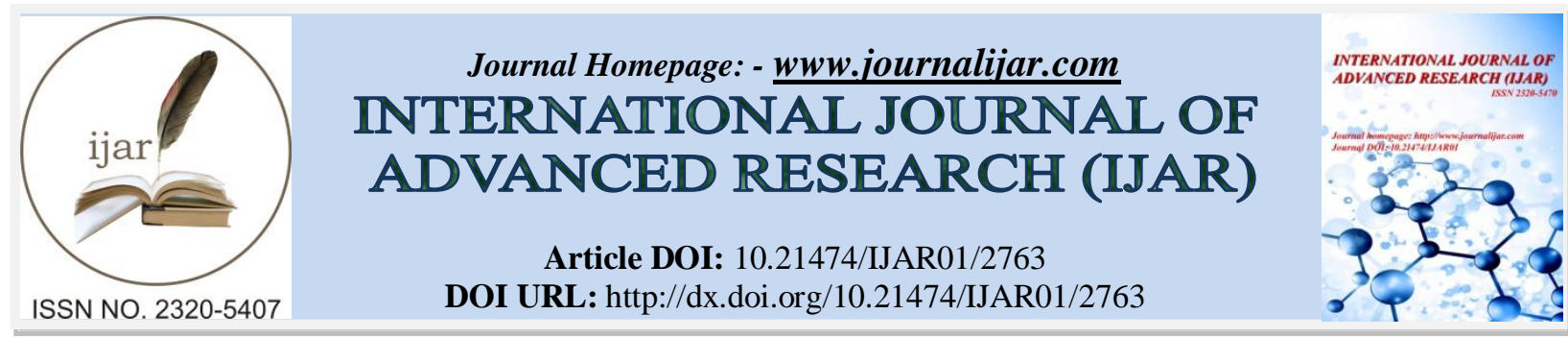

RESEARCH ARTICLE

\title{
THE INTERSTATE (ASSAM AND GUJARAT) DIFFERENCES IN THE ENVIRONMENTALLY ADJUSTED GSDP
}

Dr. Mary Vimochana.

Associate Professor, Head, Department of Economics, N.E.S. Ratnam College, Mumbai - 400078.

\section{Manuscript Info}

\section{Manuscript History}

Received: 15 November 2016

Final Accepted: 17 December 2016

Published: January 2017

Key words:-

Environmental Accounting, degradation, Sustainable development, GSDP.

\section{Abstract}

Environmental issues play a major role in the economic development of a country. It is an indispensable component for bringing about sustainable development. Environmental accounting refers to the compilation of data relating to the environment and natural resources into an accounting framework.

The objective of the study is to address the issues of environmental accounting for oil and gas resources in India and particularly for the states of Assam and Gujarat.

The present study is both analytical and empirical in its framework. It is based on select states of India, namely, Assam and Gujarat. According to literature on environmental accounting, the current national income measures did not provide adequate indicators of sustainable development of natural resources, as they exclude depletion and degradation of exhaustible resources.

As the conventional national accounts neglects depletion and degradation of natural resources, it is necessary to devise an analytical framework to assess the present situation in relation to the need for developing a practical approach which will establish a clear understanding of the relationship about Gross State Domestic Product (GSDP). The empirical analysis is based on the market valuation methods like Net Price Method and User Cost Method. These two methods are used to measure the economic value of natural capital depletion in the petroleum sector.

In this study the state level accounts are adjusted by compiling physical and monetary accounts for oil and gas resources and these accounts are then incorporated in GSDP.

The analysis presented in the study highlights the interstate (Assam and Gujarat) differences in the Environmentally Adjusted GSDP. The sensitivity of the estimated value to the choice of the methodology used (Net Price and User Cost) is also highlighted. The adoption of basic elements of green accounting will portray sustainability of resources in these states.

Copy Right, IJAR, 2016,. All rights reserved.

\section{Introduction:-}

Environmental aspects are gaining importance in the political and economic agenda of developing countries. Apart from this environmental degradation seriously threatens economic and social progress. Environmental accounts 
capture the interaction between environment and economy and also serve as a better measure for sustainable development of an economy.

Gross Domestic Product (GDP) is a national accounting term that accounts for the domestic output measured in value terms minus costs associated with input of goods and services. Thus GDP measures the value added of production, a value added that is available for payment of use of input factors like capital and labour. Environmental accounting takes care of the draw backs of conventional accounting. The correction helps to take into account the depletion of non-renewable resources, as well as various damages to the environment due to pollution to air, water and soil and also sometimes loss of eco system services due to pollution from economic activities.

Environmental accounting is an attempt to include measures of the depletion of important natural resources in the national income accounts to provide better measures of long sustainable development (Foy 1991) ${ }^{1}$. Thus environmental accounting, by working towards valuing depletion and degradation can help to prioritise the relative importance of environmental issues.

\section{Objective:-}

The main objective of this study is to analyse physical and monetary accounts for the mineral resources (Oil and Natural Gas) for Assam and Gujarat and to calculate Environmentally Adjusted GDP (GSDP).

\section{Methodology:-}

This study examines the natural capital depletion in India from 1991-2007. Market valuation method are used to measure the economic value of natural capital depletion in petroleum sector in Assam and Gujarat. Assam and Gujarat were specifically chosen because there is a higher probability of discovery of reserves of oil and gas in these states. The User Cost Method proposed by El Serafy $(1989)^{2}$ is followed in the estimation of natural asset depletion of oil and gas resources in India. The following formula is used to calculate the user-cost:

If $\mathrm{R}$ is the annual net revenues from the sales of the resource, assumed to be constant over its lifetime (of $\mathrm{n}$ years), a "true income" element X can be calculated such that

$\mathrm{R}-\mathrm{X}$ represents a "capital" element whose accumulated investment at an interest rate $\mathrm{r}$ during the $\mathrm{n}$ years would create a permanent income stream of income of $X$ (per annum). $X$ is calculated as $X=R\left[1-1 /(1+r)^{n+1}\right]$ and the user cost $R-X=R /(1+r)^{n+1}$

i.e. the discounted (last) net revenue.

It is noticed that the user-cost method acts as a special case of defining depreciation as the change in the discounted value of a resource, e.g. over one year of exploitation, assuming that the yearly net returns are the same for the remaining life of the resource.

\section{Sources of Data:-}

Data used for reserves were collected from the compiled reports of the Ministry of Petroleum and Natural Gas $(\mathrm{MoPNG})^{3}$. For Physical account, information about extraction of oil and Natural Gas is publicly available from Annual reports of the Ministry of Petroleum and Natural Gas. National Accounts Statistics ${ }^{4}$, an annual publication with time series data since 1988 -2008(CSO, 2008)

\section{Review of Literature:-}

Repetto et al. (1989) ${ }^{\mathbf{5}}$, one of the best known natural resource accounting studies is the pioneering exercise by the World Resource Institute for Indonesia. They considered the changes in the stocks of natural resources (oil, forests and soil) in the capital and flow accounts. The valuation principle assumed for oil and forests (timber) is the net price method: rents are determined by the international resource commodity price less all factor costs incurred in extraction. This implies that domestic and international markets for these resources are assumed to be perfect, and optimal paths of extraction follow Hotelling Rule.

Vincent, et.al (1997) ${ }^{6}$ examined the empirical significance of capital gains for petroleum depletion in Indonesia. The study covered the period 1971-1984 and included three resources, petroleum, timber and agricultural soils. For the calculation of economic depreciation of the resources, the study considered marginal cost. It assumed a discount rate of $12.5 \%$. The results revealed that the capital gains associated with the rise in prices are much smaller than the 
Hotelling rent estimates. It is understood that Indonesia has to invest more than the Hotelling rent due to the rise in price of oil.

European Commission (2000) ${ }^{7}$ presented the framework for the subsoil asset accounts for several countries and was developed by the Euro Stat Task Force on Subsoil Assets, and has been tested in pilot studies in several countries. The numerical results and methodological findings of the pilot studies are documented .The subsoil accounts consist of balance sheets for oil and gas in physical and monetary terms, and parts of the production and capital accounts of the oil and gas extraction industry, as well as an estimate of the resource rent from extraction. They presented the physical balance sheets, which show stocks and changes in stocks of oil and gas in physical terms.

The main results of the study are as follows:

$\bullet$

U-15 proven subsoil reserves of oil can be estimated at 1 billion tones and the proven reserves of gas at 3.1 trillion standard cubic meters at the end of 1999.

$\bullet$

ith the inclusion of Norway has brought the proven reserves of oil in the European Economic Area (EEA) to 2.4 billion tones and the reserves of gas to 4.3 trillion $\mathrm{Sm} 3$. This is around $1.7 \%$ of the world's proven reserves of oil and $3.0 \%$ of the gas reserves.EU-15 has discovered reserves of oil, which include proven reserves as well as other discovered

$\bullet$

eserves with a lower probability of being produced can be estimated at 1.5 billion tones in 1999, i.e. around $50 \%$ higher than the proven reserves. EEA also discovered that oil reserves were about 4.1 billion tones. The reserves of gas are estimated at 7.7 trillion standard cubic meters in 1999, with 3.9 trillion standard cubic meters for the EU-15.

Cairns (2008) ${ }^{8}$ argued that income is flow of value to society; therefore, an economic modeler's choice of concept of value imposes a concept of income. The argument is used to distinguish three concepts of national income.

$\mathrm{n}$ a discounted utilitarian model, which is usually the basis for theoretic discussion of net national income, the formulation of value imposes a concept of income that is not observable and hence does not provide income statistics.

$\bullet$

n a perfectly competitive economy, national income is, in principle observable. Study of competitive model provides a theoretical foundation for national accounting, with extension to distorted economies. However, two unobservable components of ideal income, consumer surplus and capital gains are neglected.

Cairns (2009) ${ }^{9}$ provided an economic analysis of oil extraction. This paper summarises the findings of conventional macroeconomic modeling, the Hotelling analysis of the extraction of and green accounting for non renewable resources such as petroleum. The study reveals that the paths of shadow prices through time are determined by adjoin conditions. The adjoint condition for resources is known as Hotelling's rule, and hence per unit depreciation rises as the rate of interest changes. The study also shows that as the oil is depleted, the pressure and consequently quantity produced declines. Further, importance is given to increase in investment in oil industry.

Atkinson and H. Gundimeda (2006) ${ }^{10}$ accounted for forest wealth in India. Changes in the timber and carbon wealth embodied in these forests are related to important green national accounting aggregates such as genuine saving and the change in wealth per capita. They found that, the annual losses due to release of carbon due to forest fires and loss in timber is $0.04 \%$ and $0.08 \%$ of GNP in India. Though the area subject to logging is less it translates into higher timber and carbon values. The contribution of forests due to harvesting timber contributes to $2.5 \%$ of GNP. However, the corresponding carbon loss due to usage of forests for timber and fuel wood is $0.53 \%$ of GNP.

Haripriya et al $(2007)^{11}$ estimated the value of educational capital formation in India by using a combination of the education stock based approach and the income and cost based approaches. The study focused only on the individuals in employment. The study found that, in all India level, the value of human capital formation is 5.1 times higher than the given fixed capital formation. The investment in education yields returns in the form of human capital, which is positive for all states. 


\section{Empirical Estimation:-}

For empirical analysis was based on Physical Account, Monetary Account and Environmentally Adjusted GSDP. Physical Account is basically a summary of the reserves and changes of natural resources during a period of time, in physical units.

\section{Physical Account:-}

Physical Account shows an equation stating that opening stock plus growth and other additional reserves minus depletion equals closing stock.

\section{Monetary Account:-}

Monetary Account is derived by the application of monetary unit values, either market prices or estimated/ imputed values, to the Physical Accounts. This account can be obtained by multiplying each unit of commodity in the physical account by its economic rent. This is explained in Table Nol and 2.

Table No:-1 Monetary Asset Accounts for Assam using Net Price Method.

\begin{tabular}{|l|l|l|l|l|l|}
\hline Year & Opening stock Rs Cr & Addition & Depletion & Net change & Closing stock \\
\hline & & Rs Cr & Rs Cr & Rs Cr & Rs Cr \\
\hline & $\mathbf{1}$ & $\mathbf{2}$ & $\mathbf{3}$ & $\mathbf{4}$ & $\mathbf{5}$ \\
\hline 1997 & 14218.04 & 2883.34 & 3011.87 & -128.53 & 14089.51 \\
\hline 1998 & 14089.51 & 25.1 & 3640.37 & -3615.27 & 10474.24 \\
\hline 1999 & 10474.24 & 4433.92 & 4555.39 & -121.47 & 10352.76 \\
\hline 2000 & 10352.76 & 1192.81 & 6185.98 & -4993.17 & 5359.59 \\
\hline 2001 & 5359.59 & 121331.1 & 9483.29 & 111848 & 117207.4 \\
\hline 2002 & 117207.4 & 92487.74 & 11045.82 & 81441.9 & 198649.3 \\
\hline 2003 & 198649.3 & 23726.79 & 12836.89 & 10889.9 & 209539.2 \\
\hline 2004 & 209539.2 & 2496.41 & 15076.77 & -12580.4 & 196958.9 \\
\hline 2005 & 196958.9 & 1207.87 & 17948.52 & -16740.7 & 180218.2 \\
\hline 2006 & 180218.2 & 9502.39 & 21872.37 & -12370 & 167848.2 \\
\hline 2007 & 167848.2 & 0 & 34415.71 & -34415.7 & 133432.5 \\
\hline
\end{tabular}

Source: $\quad$ The data for column1, $2 \& 3$ are obtained by multiplying the physical assets by the average of net price. Column 4 is obtained by subtracting column 3 from 2.

Column 5 is calculated by $[(1+2)-3]$.

The table1 indicates the Monetary Asset Account for Assam using net price method. It shows that the opening stock in 1997 was Rs. $14218.04 \mathrm{Cr}$ and it has increased to Rs. 1, 67,848.2 Cr in 2007, whereas the closing stock was Rs. $14089.51 \mathrm{Cr}$ in 1997 and increased to Rs.1,33, $432.5 \mathrm{Cr}$ in 2007, but it was almost 20.5\% less than that in 2006.

Table No: 2:- Monetary Asset Accounts for Gujarat using Net Price Method.

\begin{tabular}{|l|l|l|l|l|l|}
\hline Year & Opening stock Rs Cr & $\begin{array}{l}\text { Addition } \\
\text { Rs Cr }\end{array}$ & $\begin{array}{l}\text { Depletion } \\
\text { Rs Cr }\end{array}$ & $\begin{array}{l}\text { Net change } \\
\text { Rs Cr }\end{array}$ & $\begin{array}{l}\text { Closing stock } \\
\text { Rs Cr }\end{array}$ \\
\hline & 1 & 2 & 3 & 4 & 5 \\
\hline 1997 & 12081.48 & 407.01 & 3705.93 & -3298.93 & 8782.45 \\
\hline 1998 & 8782.46 & 0 & 4418.66 & -4418.66 & 4363.79 \\
\hline 1999 & 4363.79 & 1925.41 & 5266.04 & -3340.63 & 1023.16 \\
\hline 2000 & 1023.17 & 9718.19 & 8053.8 & 1664.39 & 2687.56 \\
\hline 2001 & 2687.56 & 98986.58 & 11034.65 & 87951.92 & 90639.48 \\
\hline 2002 & 90639.59 & 72863.18 & 12587.75 & 60275.43 & 150914.92 \\
\hline 2003 & 150914.91 & 38263.17 & 15328.37 & 22934.84 & 173849.73 \\
\hline 2004 & 173849.74 & 2634.01 & 18359.46 & -15725.46 & 158124.36 \\
\hline 2005 & 158124.39 & 1970.73 & 20194.74 & -18224.53 & 139900.34 \\
\hline 2006 & 139900.36 & 29238.13 & 27270.17 & 1967.95 & 141868.28 \\
\hline 2007 & 141868.28 & 0 & 40357.05 & -40357.24 & 101511.27 \\
\hline
\end{tabular}

Source: $\quad$ The data for column $1,2 \& 3$ are obtained by multiplying the physical assets by the average of net price. Column 4 is obtained by subtracting column 3 from 2 . 
Column 5 is calculated by [(1+2)-3].

Table 2 reveals the Monetary Asset Account of Gujarat for the period 1997-2007. It shows that the opening stock in 1997 was Rs. $12081.48 \mathrm{Cr}$ and in 2007 it was Rs. $1,41,868.28 \mathrm{Cr}$. In case of the closing stock, it was Rs8782.45. Cr in 1997 and increased to Rs.1, 01,511. 27 Cr in 2007, which was almost 28.4\% less than that in 2006.

\section{Calculation of Environmentally Adjusted GSDP:-}

The current focus of research on integrating environment into national account is primarily concentrated on adjusting GDP. The United Nations has developed a framework for calculating an Environmentally Adjusted GDP (EGDP). Natural resource accounting provides a measure of environment degradation and resource depletion, which are used to adjust the conventional GDP. This study considers only User Cost approach to calculate oil and gas adjusted national accounts.

Table No: 3:- Adjusted GSDP based on User Cost Method for Assam

\begin{tabular}{|c|c|c|c|c|c|c|}
\hline \multirow[t]{2}{*}{ Year } & \multirow{2}{*}{$\begin{array}{l}\text { GS DP } \\
\text { Rs Cr }\end{array}$} & \multirow{2}{*}{$\begin{array}{l}\text { UC } \\
\text { Rs Cr }\end{array}$} & \multirow{2}{*}{$\begin{array}{l}\text { Adjusted GSDP } \\
\text { Rs Cr }\end{array}$} & \multirow{2}{*}{$\begin{array}{l}\mathrm{UC} \text { as } \% \\
\text { GSDP }\end{array}$} & \multicolumn{2}{|c|}{ Growth Rate } \\
\hline & & & & & GSDP \% & $\begin{array}{l}\text { Adj GSDP } \\
\%\end{array}$ \\
\hline & 1 & 2 & 3 & 4 & 5 & 6 \\
\hline 1997 & 29353.74 & 644.83 & 28708.91 & 2.19 & 2.35 & 2.65 \\
\hline 1998 & 30273.85 & 825.12 & 29448.74 & 2.72 & 3.13 & 2.57 \\
\hline 1999 & 34205.13 & 1085.4 & 33119.75 & 3.17 & 12.98 & 12.46 \\
\hline 2000 & 38277.02 & 1041.9 & 37235.08 & 2.72 & 11.9 & 12.42 \\
\hline 2001 & 38034.68 & 2508.7 & 35525.94 & 6.59 & -0.63 & -4.59 \\
\hline 2002 & 39957.93 & 1777.4 & 38180.56 & 4.44 & 5.05 & 7.47 \\
\hline 2003 & 42428.03 & 1323.9 & 41104.1 & 3.12 & 6.18 & 7.65 \\
\hline 2004 & 42833.65 & 1502.1 & 41331.53 & 3.5 & 0.95 & 0.55 \\
\hline 2005 & 53397.72 & 2441.7 & 50956.05 & 4.57 & 24.66 & 23.28 \\
\hline 2006 & 52886.55 & 2007.8 & 50878.73 & 3.79 & -0.95 & -0.15 \\
\hline 2007 & 50164.15 & 3433.2 & 46730.92 & 6.84 & -5.14 & -8.15 \\
\hline
\end{tabular}

Source: Data for column 1are taken from National Accounts statistics (2008).

Data for Column 2 is calculated using the same procedure done for user cost calculation for India.

Column 3 is the difference between column $1 \& 2$.

Column 4 is derived by dividing column 2 by column 1 .

Column 5 is derived by NNP of (current year minus previous year) divided by previous year* 100 .

Column 6 is by applying Adj NNP of (current year minus previous year) divided by previous year*100.

Table No :- 4 Adjusted GSDP based on User Cost Method for Gujarat

\begin{tabular}{|l|l|l|l|l|l|l|}
\hline Year & GSDP & UC & Adj GSDP & UC as \% of GSDP & \multicolumn{2}{|l|}{ Growth Rate } \\
\cline { 6 - 7 } & Rs Cr & Rs Cr & Rs Cr & & GSDP \% & Adj GSDP \% \\
\hline & $\mathbf{1}$ & $\mathbf{2}$ & $\mathbf{3}$ & $\mathbf{4}$ & $\mathbf{4}$ & $\mathbf{6}$ \\
\hline 1997 & 112918 & 1218.1 & 111700 & 1.079 & 11.14 & 11.41 \\
\hline 1998 & 122893 & 1560.3 & 121333 & 1.27 & 8.83 & 8.624 \\
\hline 1999 & 129198 & 1847.7 & 127351 & 1.43 & 5.13 & 4.96 \\
\hline 2000 & 141910 & 2407.8 & 139502 & 1.697 & 9.83 & 9.542 \\
\hline 2001 & 134602 & 4239 & 130363 & 3.149 & -5.15 & -6.551 \\
\hline 2002 & 143759 & 3384.2 & 140375 & 2.354 & 6.8 & 7.68 \\
\hline 2003 & 159695 & 3229.7 & 156465 & 2.022 & 11.08 & 11.46 \\
\hline 2004 & 178872 & 3763.7 & 175108 & 2.104 & 12.01 & 11.92 \\
\hline 2005 & 189118 & 4754.9 & 184363 & 2.514 & 5.72 & 5.286 \\
\hline 2006 & 210517 & 5240.2 & 205277 & 2.489 & 11.32 & 11.34 \\
\hline 2007 & 228714 & 7487.6 & 221227 & 3.274 & 8.64 & 7.77 \\
\hline
\end{tabular}

Source: Data for column 1are taken from National Accounts statistics (2008).

Data for Column 2 is calculated using the same procedure done for user cost calculation for India.

Column 3 is the difference between column $1 \& 2$. 
Column 4 is derived by dividing column 2 by column 1 .

Column 5 is derived by NNP of (current year minus previous year) divided by previous year* 100 .

Column 6 is by applying Adj NNP of (current year minus previous year) divided by previous year* 100 .

The Adjusted GSDP in Assam was 12.42\% in 2000 and became negative i.e. $-8.15 \%$ in 2007 whereas in Gujarat it was $9.54 \%$ in 2000 and declined marginally to $7.77 \%$ in 2007

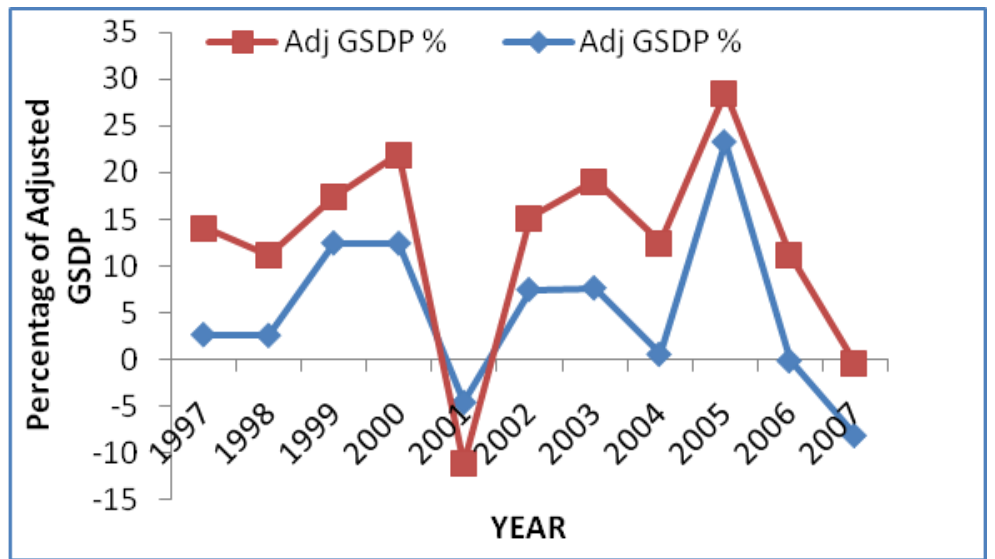

From the figure 1, it is clear that, the user cost approach yielded fluctuating values. When we compare the adjusted values of the two states, we find that though the Assam's Adjusted GSDP was less than that of Gujarat, the fluctuations in the growth rate of Adjusted GSDP was less erratic in Assam than in Gujarat.

\section{Findings:-}

1 .

ue to changes in the Exploration Policy of the Government in 1997 and public and private participation in the petroleum industry, the discovery of both oil and gas resources in various states had started increasing. As a result, the stock of the known reserves in India and the states of Assam and Gujarat also showed an increasing trend.

2.

he Monetary Asset Account for Assam using net price method. It shows that the opening stock in 1997 was Rs.14218.04 Cr and it has increased to Rs. 1, 67,848. 2 Cr in 2007, whereas the closing stock was Rs.14089.51 Cr in 1997 and increased to Rs. 1,33,432.5 Cr in 2007, but it was almost 20.5\% less that in 2006.

3 .

he Monetary Asset Account of Gujarat for the period 1997-2007. It shows that the opening stock in 1997 was Rs. $12081.48 \mathrm{Cr}$ and in 2007 it was Rs. 1, 41,868.28 Cr. In case of the closing stock, it was Rs8782.45. Cr in 1997 and increased to Rs.1, 01,511. 27 Cr in 2007, which was almost $28.4 \%$ less than that in 2006.

4.

n the case of Assam the stock of reserves reached its peak level at 343.2 MMT in 2004. From 2004 onwards, the stock of the reserves started to decrease closing at a level of 316.68 MMT. In terms of extraction, the highest level was recorded in 2005 and the lowest in 2000. With respect to Gujarat, the opening stock of oil and natural gas was estimated at 279.80 MMT in 2004 and in 2007 it was declined to 263.90 MMT.

5 .

$t$ the end of the accounting period Gujarat's GSDP has increased more than that of Assam. In 2007 the Adjusted GSDP value of Assam is Rs. 46,730.92 Cr when compared to Rs. 2, 21, 226.50 Cr for Gujarat.

6.

The user cost approach yielded fluctuating values. When we compare the adjusted values of the two states, we find that though the Assam's Adjusted GSDP was less than that of Gujarat, the fluctuations in the growth rate of Adjusted GSDP was less erratic in Assam than in Gujarat.

\section{Summary and Conclusion:-}

The aim of the present study is to explore the importance of oil and gas resources for the states of Assam and Gujarat by calculating environmentally adjusted output. In Gujarat, a large number of private sector firms have entered into exploration activities. This also increases the probability of discovery of reserves. 
In the case of Assam the stock of reserves reached its peak level at 343.2 MMT in 2004. From 2004 onwards, the stock of the reserves started to decrease closing at a level of $316.68 \mathrm{MMT}$. In terms of extraction, the highest level was recorded in 2005 and the lowest in 2000.

Though there are difficulty in the measurement of natural resources on monetary basis, countries should introduce long term policies and plan to bring about sustainable development. Further, by adopting these methods of calculating natural resource depletion, it is felt that user cost method indicates a value for natural capital depletion twice that was found using the depreciation method. This result as claimed by many economists show that the depreciation Method places a high value on resource discoveries, allowing the anomalous situation where by the net output exceeds gross output.

\section{References:-}

1. Foy E (1991), 'Accounting for Non-renewable Natural Resources in Louisiana's Gross State Product', Ecological Economics Vol.3, 25-41.

2. El Serafy S and E Lutz, (1989), 'Environmental and Resource Accounting: An overview', in: Y Ahmad, S. El Serafy and E. Lutz, (eds.) Environmental Accounting for Sustainable Development World Bank, Washington, DC.

3. Government of India (1988-2008), Annual Reports of Ministry of Petroleum and Natural Gas.

4. National Accounts Statistics , Central Statistical Organization (2006), National Account Statistics: CSO, Govt of India, New Delhi:

5. Repetto R. (1989), 'Balance-Sheet Erosion: How to Account for the Loss of Natural Resources, International Environmental Affairs, Vol.1, 103-137

6. Vincent J., T Panayotou, and J., Hartwick, J., (1997), 'Resource Depletion and Sustainability in Small Open Economies,' Journal of Environmental Economics and Management Vol.33, 274-86.

7. Hotelling H. (1931), 'The Economics of Exhaustible Resources' Journal of Political Economy Vol.39, $135-179$.

8. European Commission (2000), 'Accounts for Subsoil Assets- Results of Pilot Studies in European Countries'. European Communities. Luxembourg.

9. Cairns (2008) ${ }^{9}$, 'Value and Income', Ecological Economics Vol.66, 417-424.

10. Cairns (2009) ${ }^{10}$, 'Green Accounting for Black Gold,” The Energy Journal Vol. 30(4), 113-139

11. Atkinson and H. Gundimeda (2006) $)^{11}$, 'Accounting for India's Forest Wealth' Ecological Economics. Vol. 59, $462-476$.

12. Haripriya G. S., P. Sukhdev, R. K. Sinha and S. Sanyal (2007), 'Natural Resource Accounting for Indian States: Illustrating the Case of Forest Resources', Ecological Economics Vol. 61, 635-649.

13. Government of India, (2004). 'Draft National Environmental Policy', Ministry of Environment and Forests, New Delhi. 